\title{
THE EFFECT OF BENZENE AND OF CARBON TETRA- CHLORIDE ON THE CONCENTRATION OF CERTAIN VITAMINS, FAT, AND NITROGEN IN THE LIVER OF THE RAT*
}

\author{
BY \\ MAURICE E. SHILS, MARTIN SASS, MARGARET WOLKE, GRACE MARKS, \\ LEONARD J. GOLDWATER, and AARON BERG \\ From the Division of Industrial Hygiene, School of Public Health and \\ Department of Pathology, College of Physicians and Surgeons, \\ Columbia University, New York City
}

This study is concerned with the effects of short term moderate dosages of benzene and of carbon tetrachloride on the content of the liver with respect to vitamins, fat, and nitrogen. The experiments were performed because of our interest in the problem of whether exposures to certain toxic agents of industrial concern alter the nutritional needs of the organism. A change in the ability of an organ or tissue to retain normal amounts of a nutrient is one mechanism by which nutritional needs may be altered. That this mechanism actually exists has been demonstrated with certain carcinogens. Thus Goerner and Goerner (1939) found that the hepatic stores of vitamin A were diminished by dibenzanthracene. A similar effect on riboflavin stores of liver in animals treated with butter yellow (Kensler, Young, and Rhoads, 1942 ; Miller, 1947), and with acetylaminofluorene has been noted (Griffin, Cook, and Luck, 1949 ; Wase and Allison, 1950).

\section{Experimental Methods and Procedure} used.

Analytical Methods.-The following methods were

Nitrogen.-The micro-Kjeldahl determination was employed with the distillate collected in $2 \%$ boric acid and ammonia measured titrimetrically.

Lipid.-Fatty acids and unsaponifiable matter were measured gravimetrically using a procedure essentially that of Leathes and Raper (1925) adapted to a small scale.

Vitamin A.-The procedure was essentially that of Lemley, Brown, Bird, and Emmett (1947).

* This study was aided by the Division of Research Grants and Fellowships of the U.S. Public Health Service.
Thiamine (Vitamin $B_{1}$ ).-Bound thiamine was released from liver tissue by treatment with clarase (diastase) in acetate buffer as described by Cheldelin, Eppright, Snell, and Guirard (1942). The vitamin was measured fluorometrically by a modification of the procedure of Hennessy (1941). To help avoid interfering substances which may not be adequately compensated for in the usual non-ferricyanide treated blank, we have employed benzene sulfonyl chloride as suggested by Urban and Goldman (1944). This substance prevents the formation of thiochrome, and its use allows both the blank and the unknown to be treated with alkaline ferricyanide. In treating the blank, the benzene sylfonyl chloride is added before ferricyanide, whereas with the unknown it is added after ferricyanide.

Riboflavin.-Bound riboflavin was released in the manner described for thiamine and the free vitamin was determined by the microbiological method of Snell and Strong (1939).

Niacin.-Homogenized liver was suspended in $1 \mathrm{~N}$ sulphuric acid autoclaved at $15 \mathrm{lb}$. pressure for 15 minutes, cooled, and brought to volume. When ready for assay, an aliquot was neutralized and assayed by the microbiological procedure of Krehl, Strong, and Elvehjem (1943).

Procedure.-Three groups of male rats* were maintained on a pellet stock diet $\dagger$ from weaning until they had reached 60 days of age. They were then placed on a purified diet (Diet 11) of the following composition : casein, $20 \ddagger$; corn oil, 10 ; cerelose, 66 ; salts, $4 \S$; with vitamins incorporated per $100 \mathrm{~g}$. of this

* Rats were randomly distributed from seven litters with as nearly equal distribution as possible of litter-mates among the three groups,

Since some of the litters were not matched in each group, the Statistical analysis employed treated the mean values of the groups as statistical analysis employed treated

coming from independent samples.

Borden B3F.

§ USP XIII No. 2. 
basal diet as follows : thiamine, $1 \mathrm{mg}$; riboflavin, $1 \mathrm{mg}$; pyridoxine, $1 \mathrm{mg}$; niacin, $1 \mathrm{mg}$; calcium pantothenate, $2.5 \mathrm{mg}$; folic acid, $0.2 \mathrm{mg}$; biotin, $0.002 \mathrm{mg}$.; choline, $50 \mathrm{mg}$.; percomorph oil, $0.12 \mathrm{ml}$.

Eight days later the treatments were started. Group I, the control group, received $0.3 \mathrm{ml}$. per rat of an $0.9 \%$ sodium chloride solution subcutaneously on the same days that group II was injected subcutaneously with 0.3 $\mathrm{ml}$. of benzene per $100 \mathrm{~g}$. of bodyweight, and group III received subcutaneously $0.1 \mathrm{ml}$. carbon tetrachloride per $100 \mathrm{~g}$. bodyweight. Injections were given on seven of the following nine days. On the tenth day all rats were killed by exsanguination and their livers weighed. Small samples of liver were taken for histological examination and the remainder immediately wrapped and frozen in solid $\mathrm{CO}_{2}$ until analyzed.

At the conclusion of the experiment Group I consisted of nine rats, Group II of 11 rats, and Group III of 11 rats. Group I rats were restricted in their food intake to maintain weight at approximately the levels of the benzene and $\mathrm{CCl}_{4}$ treated rats.

\section{Results}

In Table 1 are listed the average bodyweights of the three groups during the experiment together with average liver weights expressed on the basis of total bodyweight and per $100 \mathrm{~g}$. of bodyweight. The control animals lost weight slightly as a result of food restriction. The benzene group decreased in weight to a greater extent, while the $\mathrm{CCl}_{4}$ group maintained weight. The $\mathrm{CCl}_{4}$ treated group had the heaviest livers, but the benzene-treated rats also had livers which were heavier than those of the controls. Calculation of liver weights per $100 \mathrm{~g}$. of bodyweight did not change this order. Statistical analysis of the liver weights by the " $t$ " test indicated that the differences among
TABLE 1

AVERAGE BODY AND LIVER WEIGHTS* OF THE EXPERIMENTAL GROUPS

\begin{tabular}{l|c|c|c}
\hline \multicolumn{1}{c|}{ Group } & Control & Benzene & $\mathrm{CCl}_{4}$ \\
\hline Number of rats & 9 & 11 & 11 \\
\hline At 1st day & 176 & 199 & 187 \\
\hline ,, 6th ,, & 168 & 190 & 192 \\
\hline , 10th ,, & 170 & 172 & 192 \\
\hline
\end{tabular}

* Liver and body weights expressed in grams $\quad=$ standard error of the mean.

Total liver weight $\quad 5 \cdot 72 \pm 0.23 \quad 7 \cdot 16 \pm 0.23 \quad 9 \cdot 68 \pm 0.29$

Liver weight per 100

g. bodyweight $\quad 3.36 \pm 0.060 \quad 4.17 \pm 0.096 \quad 5.08 \pm 0.180$

Difference (g.)

0.81

$1 \cdot 72$

0.91

Significance (P)

$<0.001<0.001$

$<0.001$

groups were highly significant on the basis of both the total and per $100 \mathrm{~g}$. bodyweight (Table 1).

In Table 2 are summarized the results of the analyses for thiamine, riboflavin, niacin, vitamin A, nitrogen, and lipid, all expressed per gram of liver. It is clear that the benzene treatment had no significant effect on the concentration of the vitamins and of the fat ; the nitrogen concentration of this group was decreased slightly but significantly below that of the controls. Carbon tetrachloride treatment, on the other hand, caused a significant drop in the concentration of all vitamins and of nitrogen. As was expected, the lipid content increased markedly, and this increase in fatty material undoubtedly accounts for some of the

TABLE 2

EFFECT OF BENZENE AND CARBON TETRACHLORIDE ON LIVER CONCENTRATION OF VITAMINS, NITROGEN, AND LIPID*

\begin{tabular}{|c|c|c|c|c|c|c|c|}
\hline Group & $\begin{array}{l}\text { No. of } \\
\text { Rats }\end{array}$ & $\begin{array}{c}\text { Thiamine } \\
(\gamma)\end{array}$ & $\begin{array}{l}\text { Riboflavin } \\
\qquad(\gamma)\end{array}$ & $\begin{array}{l}\text { Niacin } \\
(\gamma)\end{array}$ & $\underset{\text { (I.U.) }}{\text { Vitamin } A}$ & $\begin{array}{l}\text { Nitrogen } \\
\text { (mg.) }\end{array}$ & $\begin{array}{l}\text { Lipid } \\
\text { (mg.) }\end{array}$ \\
\hline I. Control & 9 & $14.6 \pm 0.85$ & $38 \cdot 3 \pm 1 \cdot 84$ & $195.9 \pm 11.6$ & $838 \cdot 4 \pm 47 \cdot 1$ & $27.9 \pm 0.55$ & $45 \cdot 6 \pm 1 \cdot 1$ \\
\hline II. Benzene & 11 & $12 \cdot 8 \pm 0.94$ & $33 \cdot 8 \pm 2 \cdot 79$ & $180.7 \pm 5.7$ & $836 \cdot 1 \pm 35 \cdot 3$ & $25 \cdot 3 \pm 0.79$ & $45 \cdot 0 \pm 1 \cdot 6$ \\
\hline III. $\mathrm{CCl}_{4}$ & 11 & $9.4 \pm 0.52$ & $23 \cdot 3 \pm 2 \cdot 53$ & $134.5 \pm 4.9$ & $676 \cdot 5 \pm 36 \cdot 1$ & $20.1 \pm 0.64$ & $166.9 \pm 5 \cdot 9$ \\
\hline \multicolumn{8}{|c|}{ Mean Differences between Groups and their Significance } \\
\hline $\begin{array}{l}\text { Between control } \\
\text { and benzene }\end{array}$ & $\underset{\mathbf{P}}{\operatorname{diff}}$ & $\begin{array}{l}1 \cdot 8 \\
0 \cdot 18\end{array}$ & $\begin{array}{l}4 \cdot 5 \\
0 \cdot 18\end{array}$ & $\begin{array}{c}15 \cdot 2 \\
0 \cdot 23\end{array}$ & $\begin{array}{l}2 \cdot 3 \\
0 \cdot 55\end{array}$ & $\begin{array}{l}2 \cdot 6 \\
0 \cdot 02\end{array}$ & $\begin{array}{l}0.6 \\
0.55\end{array}$ \\
\hline $\begin{array}{l}\text { Between control } \\
\text { and } \mathrm{CCl}_{4}\end{array}$ & $\underset{\mathbf{P}}{\operatorname{diff} .}$ & $\begin{array}{c}5 \cdot 2 \\
<0.001\end{array}$ & $\begin{array}{l}15.0 \\
<0.001\end{array}$ & $\begin{array}{l}61.4 \\
<0.001\end{array}$ & $\begin{array}{r}161 \cdot 9 \\
0.01\end{array}$ & $\begin{array}{c}7 \cdot 8 \\
<0.001\end{array}$ & $\begin{array}{l}121 \cdot 3 \\
<0.001\end{array}$ \\
\hline $\begin{array}{l}\text { Between benzene } \\
\text { and } \mathrm{CCl}_{4}\end{array}$ & $\underset{\mathbf{P}}{\operatorname{diff} .}$ & $\begin{array}{c}3.4 \\
<0.001\end{array}$ & $\begin{array}{c}10 \cdot 5 \\
0 \cdot 01\end{array}$ & $\begin{array}{l}46 \cdot 2 \\
<0 \cdot 001\end{array}$ & $\begin{array}{l}159 \cdot 6 \\
0.004\end{array}$ & $\begin{array}{c}5 \cdot 2 \\
<0 \cdot 001\end{array}$ & $\begin{array}{l}121.9 \\
0.001\end{array}$ \\
\hline
\end{tabular}

* Mean per g. of liver \pm Standard error of the mean. 
differences in vitamin and nitrogen concentrations.

Calculations made on the basis of estimated fatfree liver weight brings the nutrient concentrations of the $\mathrm{CCl}_{4}$-treated rats closer to those of the controls (Table 3). However, with the exception of vitamin A, the differences are still considerable. Further calculation on the basis of equal nitrogen content per gram of liver brings the concentrations of the water-soluble vitamins of the two groups much more closely into line with each other (Table 3).

TABLE 3

LIVER CONCENTRATION OF VITAMINS AND NITROGEN OF $\mathrm{CCl}_{4}$ TREATED RATS* (PFRCENTAGE OF CONTROL)

\begin{tabular}{c|c|c|c|c|c}
\hline Basis & $\begin{array}{c}\text { Thia- } \\
\text { mine } \\
(\%)\end{array}$ & $\begin{array}{c}\text { Ribo- } \\
\text { flavin } \\
(\%)\end{array}$ & $\begin{array}{c}\text { Nia- } \\
\text { cin } \\
(\%)\end{array}$ & $\begin{array}{c}\text { Vita- } \\
\text { min A } \\
(\%)\end{array}$ & $\begin{array}{c}\text { Nit- } \\
\text { rogen } \\
(\%)\end{array}$ \\
\hline Wet weight* & $64 \cdot 4$ & $61 \cdot 0$ & $68 \cdot 8$ & $80 \cdot 7$ & $72 \cdot 1$ \\
\hline Fat-free $\dagger$ & 74.9 & $71 \cdot 0$ & $80 \cdot 3$ & $95 \cdot 3$ & 83.9 \\
\hline Equal $\mathrm{N}_{+}^{+}$ & 90.0 & 84.9 & 95.0 & $112 \cdot 7$ & $100 \cdot 0$ \\
\hline
\end{tabular}

* As actually determined from Table 2.

† Fat free concentrations calculated by multiplying concentrations on wet weight basis by factor of $100 \div(100-\mathrm{mg}$. neutral fat $)$. Neutral fat value taken as $110 \%$ of lipid value as given in Table 2 .

¥ The observed values of $\mathrm{CCl}_{4}$ treated livers (Table 2) were multiplied by 1.39 ; i.e. $\mathrm{N}$ content of controls $\div \mathrm{N}$ content of $\mathrm{CCl}_{4}$ treated rats.

Despite the differences observed in concentration of nutrients per gram of liver, calculation of the total liver content revealed that the $\mathrm{CCl}_{4}$ group had as much or more of each of the nutrients compared to the benzene and control groups (Table 4). The content of the water-soluble vitamins was not significantly different in the three groups, but there was a significantly greater amount of fat, vitamin $\mathrm{A}$, and nitrogen in the larger liver of the $\mathrm{CCl}_{4}$-treated rats. The same tendency was noted for the latter three substances in the livers of the benzene-treated animals; fat and vitamin A content were significantly higher than in the controls while the nitrogen increase was of doubtful significance $(P=\cdot 07)$.
Histological examination of the livers of a number of the rats was made following fixation in Bouin's solution and staining with hematoxylin-eosin. In all seven of the 11 rats treated with $\mathrm{CCl}_{4}$, whose livers were examined, there was marked fatty infiltration ; six showed varying degrees of necrosis of the central half of the liver lobule while the seventh animal had all of the lobule involved except a narrow zone in the portal area. Of the six benzene-treated animals examined, the liver showed no obvious changes in four, while in two there was a slight fatty infiltration of cells about the central veins. Livers of the nine control rats appeared normal.

\section{Discussion}

The interesting point in this study is that despite rather marked reductions in the vitamin concentrations per gram of liver of $\mathrm{CCl}_{4}$-treated rats, the overall contents in the liver were as great as, or greater, than in the controls. One question that arises is whether the vitamins in the damaged livers are as available to the organism as those of normal animals. Some attention has been given to this problem by other investigators in the case of vitamin A. Popper, Steigmann, and Dyniewicz, (1942) studied the distribution of this vitamin, using fluorescence microscopy, in the livers of $\mathrm{CCl}_{4}$ treated rats. They noted that the vitamin tended to accumulate rather quickly in areas of fatty degeneration and less rapidly in normal sites. Chemically, less vitamin A was stored in the liver of vitamin A-deficient rats with $\mathrm{CCl}_{4}$ intoxication than in non-poisoned control deficient rats following vitamin $\mathrm{A}$ feeding. They suggest that the $\mathrm{CCl}_{4}{ }^{-}$ damaged liver releases its vitamin A more slowly than does normal hepatic tissue with resulting lowered plasma levels.

Haig and Post (1941) analyzed the livers of rats for vitamin $\mathrm{A}$ three months following an eightweek period of $\mathrm{CCl}_{4}$ administration. They found no correlation between the concentration of vitamin $A$ in the cirrhotic livers, the liver weight, or the degree of fibrosis; however, the livers of the

TABLE 4

EFFECT OF BENZENE AND CARBON TETRACHLORIDE ON NUTRIENT CONTENT OF TOTAL RAT LIVER*

\begin{tabular}{c|c|c|c|c|c|c|c}
\hline Group & $\begin{array}{c}\text { Mean } \\
\text { Liver } \\
\text { Weight } \\
(\mathrm{g} .)\end{array}$ & $\begin{array}{c}\text { Thiamine } \\
(\gamma)\end{array}$ & $\begin{array}{c}\text { Riboflavin } \\
(\gamma)\end{array}$ & $\begin{array}{c}\text { Niacin } \\
(\gamma)\end{array}$ & $\begin{array}{c}\text { Vitamin A } \\
(\text { I.U.) }\end{array}$ & $\begin{array}{c}\text { Nitrogen } \\
(\mathrm{mg})\end{array}$ & $\begin{array}{c}\text { Lipid } \\
(\mathrm{mg} .)\end{array}$ \\
\hline I. Control & $5 \cdot 72$ & $83 \pm 5 \cdot 1$ & $219 \pm 12$ & $1114 \pm 78$ & $4789 \pm 317$ & $162 \pm 7 \cdot 4$ & $257 \pm 12$ \\
II. Benzene & $7 \cdot 16$ & $91 \pm 6 \cdot 1$ & $240 \pm 19$ & $1291 \pm 51$ & $5957 \pm 251$ & $181 \pm 6.7$ & $325 \pm 10$ \\
III. $\mathrm{CCl}_{4}$ & $9 \cdot 68$ & $91 \pm 6 \cdot 0$ & $226 \pm 15$ & $1298 \pm 55$ & $6523 \pm 468$ & $193 \pm 6.5$ & $1622 \pm 117$ \\
\hline
\end{tabular}

* (Mean \pm Standard Error.) 
treated animals contained much less vitamin A than did those of the controls. These studies suggest the need for serial studies of plasma vitamin A levels, liver vitamin A content, and histological structure in order to correlate vitamin availability and storage with the changing morphology of the damaged and healing liver.

One would expect much higher vitamin A concentrations in the livers of the $\mathrm{CCl}_{4}$-treated animals than in those of the controls if vitamin $\mathrm{A}$ is deposited preferentially in areas of fatty degeneration, as Popper and others (1942) have described. Our results were to the contrary, but we draw no definite conclusions on this aspect, since vitamin A intake was not rigidly controlled in our study. It should be noted also that there did not appear to be any correlation between total liver fat and total vitamin $\mathrm{A}$. The $\mathrm{CCl}_{4}$-treated rats had an increase in total fat above the controls of over $500 \%$ associated with a vitamin $\mathrm{A}$ increase of $36 \%$; the benzene-treated rats had an increase in total fat above controls of only $26 \%$ associated with an increased vitamin A of $24 \%$.

\section{Summary}

The effects of moderate subcutaneous doses of benzene and of carbon tetrachloride administered over a period of nine days have been investigated with respect to changes in the concentration and total content of thiamine, riboflavin, niacin, vitamin $A$, fat, and total nitrogen in the livers of rats.

Carbon tetrachloride caused a marked increase in liver weight and liver fat. On the other hand, there was a significant decrease in the concentration of the vitamins and nitrogen per gram of liver.
Benzene treatment had no significant effect on the concentration of vitamins, but was associated with a slight decrease in nitrogen concentration and some increase in liver weight.

Because of the increased weight of the livers in the $\mathrm{CCl}_{4}$-treated rats, the total amounts of the watersoluble vitamins in the livers of this group were about the same as in the livers of the benzene and control groups. Total vitamin $\mathrm{A}$ was greater in the $\mathrm{CCl}_{4}$ - and benzene-treated groups than in the controls, but the increases were not proportional to change in total liver fat.

Histologically, the changes in nutrient concentration in the livers of the $\mathrm{CCl}_{4}$-treated rats were associated with marked fatty infiltration and necrosis of the central half of the liver lobule. Of the benzene-treated rats whose livers were studied, there were no obvious changes in the majority, while some showed slight fatty infiltration about the central veins.

\section{REFERENCES}

Cheldelin, V. H., Eppright, M. A., Snell, E. E., and Guirard, B. M. (1942). Univ. Texas Publ. No. 4237, p. 15. Austin, Texas. Goerner, A. A., and Goerner, M. M. (1939). J. Nutrit., 18, 441. Goerner, A. A., and Goerner, M. M. (1939. Jutrit., 18, 441. 17 Haig, C., and Post, J., (1941). Proc. Soc. exp. Biol., N.Y., 48, 710. Hennessy, D. J. (1941). Industr. Engng. Chem. (Anal. Ed.), 13, 216.

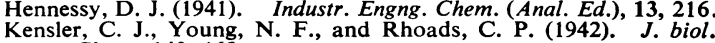
Kensler, C. J., Young,

Krehl, W. A., Strong, F. M., and Elvehjem, C. A. (1943). Industr. Engng. Chem. (Anal. Ed.) 15, 471.

Leathes, J. B., and Raper, H. S. (1925). "The Fats", 2nd ed. London.

Lemley, J. M., Brown, R. A., Bird, O. D., and Emmett, A. D. (1947).

Miller, J. Autrit., 33, 53 . 1947 . N.Y. Acad. Sci., 49, 19.

Mopper, H., Steigmann, F., and Dyniewicz, H. A. (1942). Proc. Popper, H., Steigmann, F., and Dyniewicz, H. A. (1942). Proc.
Soc. exp. Biol., N.Y., 50, 266. Snell, Eoc. Exp. Biol., N.Y., 50, 266. (1939). Industr. Engng. Chem. (Anal. Ed.) 11, 346.

Urban, F., and Goldman, M. L. (1944). J. biol. Chem., 152, 329. Wase, A. W., and Allison, J. B. (1950). Proc. Soc. exp. Biol., N.Y. 73, 147 . 